\title{
Assessing the Ability of Banks to Manage the Credit Risks of Their Enterprise Customers-From the Perspectives of Banking Act and Banking Supervision Law
}

\author{
Sang-Bing Tsai ${ }^{1}$ \\ ${ }^{1}$ Law School, Nankai University, Tianjin 300071, China \\ E-mail:sangbing@hotmail.com
}

\begin{abstract}
In the rapidly changing global financial environment, credit risk control and management is the top priority for banks. This study explores the ability of one bank in Taiwan to assess the credit risks of their enterprise customers. Importance-performance analysis (IPA) is commonly used to assess performance and to analyze competitive strategies. Therefore, this study adopts IPA to investigate the ability of a bank to assess credit risks, facilitating the bank to develop strategies for assessing credit risks. According to the results of this study, Bank A should keep up the good work regarding three indicators (enterprise repayment evaluation ability, enterprise capital turnover evaluation ability, and product market share evaluation ability). These indicators reflect the advantages of Bank A, and should thus be maintained to enhance its performance.
\end{abstract}

Keywords: bank credit, credit assessment, decision making, Banking Supervision Law, Banking Act, Importance-Performance Analysis Model

\section{Introduction}

Bank credit risk management involves the development of a credit policy to guide and coordinate business activities, investigate customer credit histories, choose payment methods, define credit limits, and ensure payments are received in a timely manner [1-2].

In practice, there is typically a credit paradox within bank credit risk management. According to risk management theory, banks should prevent credit centralization, particularly when the conventional credit-risk-management model is ineffective at hedging credit risks. However, decentralizing investment risks is challenging in practice [3-4]. The main reasons for this credit paradox are as follows [5-6]: (1) Banks typically assess the credit of most small and medium enterprises without considering their credit rating, instead typically considering only the long-term business relationship between themselves and the enterprise; therefore, banks tend to loan only to their existing customers. (2) Some banks loan only to enterprises in a certain industry with which the bank is familiar. (3) Loan diversification decreases the amount of loan to be lent, preventing banks from attain economies of scale through issuing loans. (4) Finally, investment opportunities sometimes lead to banks loaning extensively to certain departments or regions.

This study explores the ability of banks in Taiwan to assess credit risks and their own 
performance. The importance-performance analysis (IPA), which is commonly used to assess performance and to analyze competition strategies, is adopted by this study to investigate the ability of a Taiwanese bank in assessing credit risks and its own performance. Accordingly, strategies are developed for improving the bank's performance at credit assessment.

\section{Literature Review}

Managing credit risks is extremely crucial for banks, particularly for banks that take financial risks to earn rewards. Credit risk refers to the risk of default on a loan because a borrower is unable to fulfill their contractual obligations (perhaps because of the deterioration of their business or disputes between themselves and their partners).

During the past 20 years, the development of credit risk management and assessment in international banking has undergone the following changes (Hu, 2003; Huang, 2013) [7-8]:

(1) Because of a debt crisis in the 1990s, banks began to emphasize the importance of credit risk management; accordingly, the Basel Accords were signed, which stipulate various weights for various types of assets so that risks can be quantified. This is a general method for analyzing bank risk.

(2) In the 1990s, some large banks became aware that credit risks are critical financial risks. Therefore, they paid more attention to how to measure them and attempted to establish a model for measuring credit risks. One framework for calculating risk-Credit Metrics-was developed by J. P. Morgan and received substantial attention.

(3) Following the Asian financial crisis in 1997, a new conclusion about world financial risks is made: Losses are not caused by a single risk but are jointly caused by credit and market risks. The financial crisis made bankers consider joint models of market and credit risks and how operation risks might be quantified. Accordingly, comprehensive risk management models received substantial attention.

Traditional credit risk management methods include the expert system, the internal rating model, and the Zeta model. However, these methods have become outdated or inaccurate because of developments in the financial industry. With the development of modern science and technology and the advance of market risk management, contemporary credit risk management has improved, with quantitative models such as the Credimetrics, KMV (Kealhofer, McQuown, and Vasicek), and Creditrisk models been proposed. However, the reliability and validity of these credit risk management models remain to be verified. Generally speaking, no existing model is able to effectively quantify credit risks $[4,7,8]$.

According to the aforementioned assertions, this study develops a credit risk assessment method that includes eight indicators: industry evaluation ability, enterprise internal control evaluation ability, enterprise financial planning evaluation ability, enterprise repayment evaluation ability, enterprise capital turnover evaluation ability, product market share evaluation ability, product innovation evaluation ability, and business strategy evaluation ability. 


\section{Method}

IPA was first proposed and used by Martilla and James (1977) [9-12]. In IPA, the average importance and performance scores are presented on a two-dimensional plot (with the vertical axis representing importance and the horizontal axis representing performance) (Fig. 1).

The definitions of the four quadrants in the IPA plot are as follows [13-18]:

(1) Keep up the good work: Customers consider the assessment indicators in this quadrant to be crucial and are satisfied with the enterprise's performance; therefore, the enterprise should "keep up the good work" on these items.

(2) Concentrate here: Customers consider the assessment indicators in this quadrant to be crucial but are not satisfied with the enterprise's performance; therefore, the enterprise should concentrate here.

(3) Low priority: Customers do not consider the assessment indicators in this quadrant to be crucial but they are dissatisfied with the enterprise's performance; therefore, the items in this quadrant have low priority.

(4) Possible overkill: Customers do not consider the assessment indicators in this quadrant to be crucial but are satisfied with the enterprise's performance; therefore, the current attention paid to the items in this quadrant is already possible overkill.

By defining these regions, managers can effectively use their limited resources to distinguish competitive advantages from competitive disadvantages, to determine improvement priorities, and to enhance management performance. IPA can be used to present performance levels. Numerous researchers have applied this method in other fields to determine improvement priorities and satisfy customers [19-24].

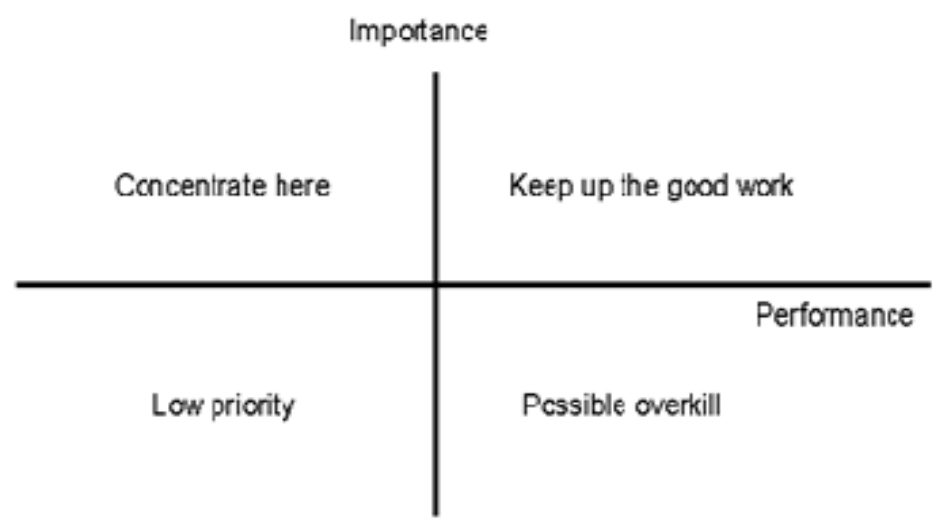

Figure 1. IPA chart

\section{Results and Discussion}

Bank A is the largest commercial bank in Taiwan and therefore selected in this study to investigate its ability to assess the credit risks posed by its enterprise customers. The questionnaire for this study employs a 9-point Likert scale and eight indicators. A total of 10 professors, 18 Bank A senior managers, and seven representatives in the association of banks participate in the questionnaire survey. Overall, 35 questionnaires are distributed, and 31 valid 
questionnaires are returned, with a valid return rate of $88.57 \%$.

The average importance (7.25) and average performance (6.73) scores are used as the criteria to determine the performance of each indicator (refer to Table 1 for details).

Table 1. Ability of Bank A to assess credit risks and improvement strategies

\begin{tabular}{llccl}
\hline Items & criteria & Importance & Performance & Improvement strategies \\
\hline 1 & Industry evaluation ability & 7.0 & 7.5 & Possible overkill \\
2 & $\begin{array}{l}\text { Enterprise internal control } \\
\text { evaluation ability }\end{array}$ & 7.1 & 5.8 & Low priority \\
3 & $\begin{array}{l}\text { Enterprise financial planning } \\
\text { evaluation ability }\end{array}$ & 7.7 & 6.9 & Keep up the good work \\
4 & $\begin{array}{l}\text { Enterprise repayment } \\
\text { evaluation ability }\end{array}$ & 8.1 & 7.8 & Keep up the good work \\
5 & $\begin{array}{l}\text { Enterprise capital turnover } \\
\text { evaluation ability }\end{array}$ & 7.2 & 7.6 & Keep up the good work \\
6 & $\begin{array}{l}\text { Product market share } \\
\text { evaluation ability }\end{array}$ & 5.8 & 6.9 & Possible overkill \\
7 & $\begin{array}{l}\text { Product innovation evaluation } \\
\text { ability }\end{array}$ & 7.7 & 5.8 & Concentrate here \\
8 & $\begin{array}{l}\text { Business strategy evaluation } \\
\text { ability }\end{array}$ & 7.4 & 5.5 & Concentrate here \\
Mean & & 7.25 & 6.73 & \\
\hline
\end{tabular}

According to the IPA, Bank A should keep up the good work regarding three indicators (enterprise repayment evaluation ability, enterprise capital turnover evaluation ability, and product market share evaluation ability).

Regarding two uncompetitive indicators (product innovation evaluation ability and business strategy evaluation ability), Bank A should concentrate here and use their resources to improve the performance of these two indicators. This could reverse its competitive disadvantages and to enhance its ability to assess customer credit.

Two indicators (industry evaluation ability and product market share evaluation ability) had low priority. Bank A has not demonstrated excellent performance in these two indicators, but they are not considered crucial. These two indicators can be improved when Bank A has extra resources.

Finally, enterprise internal control evaluation ability attains a low importance score but high performance score, implying that the effort spent on it was possible overkill. Excellent performance for this item does not lead to higher profits, so company resources would be better used elsewhere. 


\section{Conclusion}

Conventional credit risk management methods mainly include the expert system, the internal rating model, and the Zeta model. Contemporary credit risk management methods include the Creditmetrics, KMV, and Creditrisk models, whose validity and reliability are questionable. Therefore, no general effective method exists that can be used to assess credit risks. In this study, a method is therefore proposed to assess the credit risks of banks' enterprise customers. According to the results of this study, Bank A should keep up the good work regarding three indicators (enterprise repayment evaluation ability, enterprise capital turnover evaluation ability, and product market share evaluation ability). These indicators reflect the advantages of Bank $A$, and should thus be maintained to enhance its performance. Regarding two uncompetitive indicators (product innovation evaluation ability and business strategy evaluation ability), Bank A should concentrate here and use its resources to improve the performance of the two indicators, thereby reversing its competitive disadvantages and enhancing its ability to assess customer credit.

\section{References:}

[1] Hu, D.Q., 2003. Financial Supervision and Financial Inspection Practices. Taipei, Taiwan: Taiwan Academy of Banking and Finance.

[2] Huang, S.R., 2013. Consumer Finance and Risk Management. Taipei, Taiwan: Taiwan Academy of Banking and Finance.

[3] Swami, M. B. 2014. The Impact of liberalization of regulation in Banking Sector: Case Study of Botswana Banking Sector. Open Journal of Finance, 6, 1-10.

[4] Shipra, Bansal \& Yash, P. T. 2014. Comparative Study on Performance Evaluation of Large Cap Equity and Debt Mutual Fund Schemes. Open Journal of Finance, 3, 1-13.

[5] Berger, A. N., Hasan, I. \& Zhou, M. 2009. Bank ownership and efficiency in China: What will happen in the world's largest nation? Journal of Banking \& Finance, 33(1), 113-130.

[6] Nuno Ferreira \& Manuela, M. O. 2014. An Analysis of Equity Markets Cointegration in the European Sovereign Debt Crisis. . Open Journal of Finance, 6, 11-19.

[7] Mora, N. 2014. Reason for Reserve? Reserve Requirements and Credit. Journal of Money Credit and Banking, 46(2), 469-501.

[8] Jiang, G. J. \& Lo, I. 2014. Private information flow and price discovery in the U.S. treasury market. Journal of Banking \& Finance, 47(10), 118-133.

[9] Tsai, S.B., Huang, C.Y., Wang, C.K., Chen, Q., et al. 2016. Using a Mixed Model to Evaluate Job Satisfaction in High-Tech Industries. Plos One, 11(5): e0154071. doi:10.1371/journal.pone.0154071

[10] Tsai, S.B. 2016. Using Grey Models for Forecasting China's Growth Trends in Renewable Energy Consumption. Clean Technologies and Environmental Policy, 18, 563-571.

[11] Zhou, J. Wang, Q., Tsai, S.B., et al. 2016. How to Evaluate the Job Satisfaction of 
Development Personnel. IEEE Transactions On Systems Man Cybernetics-Systems. 10.1109/TSMC.2016.2519860.

[12] Su, J.M., Lee, S.C., Tsai, S.B., et al. 2016. A Comprehensive Survey of the Relationship between Self-efficacy and Performance for the Governmental Auditors. SpringerPlus, 5:508. DOI: 10.1186/s40064-016-2104-X.

[13] Qu, Q., Chen, K.Y., Wei, Y.M., et al. 2015. Using Hybrid Model to Evaluate Performance of Innovation and Technology Professionals in Marine Logistics Industry Mathematical Problems in Engineering, Article ID 361275, 8 pages, http://dx.doi.org/10.1155/2015/361275.

[14] Tsai, S.B., Xue, Y., Zhang, J., et al. 2016. Models for Forecasting Growth Trends in Renewable Energy. Renewable \& Sustainable Energy Reviews. DOI: 10.1016/j.rser.2016.06.001.

[15] Lee, Y.C., Chu, W.H., Chen, Q., et al. 2016. Integrating DEMATEL Model and Failure Mode and Effects Analysis to Determine the Priority in Solving Production Problems. Advances in Mechanical Engineering, 8(4), 1-12.

[16] Huang, P.Y., Wu, T.S., Chen, L.J., Tsai, S.B., et al. 2015. An Empirical Research on Management Innovation of High Technology Manufacturers. Advances in Mechanical Engineering, 7(7), 1-14. DOI: 10.1177/1687814015593679.

[17] Chang, S.F., Chang, J.C., Lin, K.H., Tsai, S.B., et al. 2014. Measuring the Service Quality of E - Commerce. International Journal of Web Services Research, 11(3), 96-115.

[18] Lee, Y.C., Wang, Y.C., Chien, C.H., Wu, C.H., et al. 2016. Applying Revised Gap Analysis Model in Measuring Hotel Service Quality, SpringerPlus,, 5:1191. DOI 10.1186/s40064-016-2823-z.

[19] Lee, Y.C., Wang, Y.C., Lu, S.C. Hsieh, Y.F., et al. 2016. An Empirical Research on Customer Satisfaction Study: A Consideration of Different Levels of Performance. SpringerPlus, 5:1577. DOI 10.1186/s40064-016-3208-z.

[20] Deng, Y. \& Chan, F.T.S. 2011. A new fuzzy dempster MCDM method and its application in supplier selection. Expert Systems with Applications, 38(8), 9854-9861.

[21] Deng,X.Y., Hu, Y., Deng Y., \& Mahadevan,S. 2014. Environmental impact assessment impact assessment based on numbers. Expert Systems with Applications, 41(2), 635-643.

[22] Hsiao-Ming Chen, Chia-Huei Wu, Sang-Bing Tsai, Jian Yu, et al. 2016. Exploring key factors in online shopping with a hybrid model. SpringerPlus, 5:2046. DOI 10.1186/s40064-016-3746-4.

[23] Sang-Bing Tsai, Kuan-Yu Chen, Hongrui Zhao, Yu-Min Wei, et al. 2016. Using a Mixed Model to Explore Evaluation Criteria for Bank Supervision: A Banking Supervision Law Perspective. PLoS ONE, 11(12): e0167710. doi:10.1371/journal.pone.0167710.

[24] Sang-Bing Tsai, Guodong Li, Chia-Huei Wu, Yuxiang Zheng \& Jiangtao Wang. 2016. An empirical research on evaluating banks' credit assessment of corporate customers. 
SpringerPlus, 5:2088. DOI 10.1186/s40064-016-3774-0. 